\title{
Production components of sunflower plants irrigated with treated domestic wastewater and drinking water in semiarid region ${ }^{1}$
}

\author{
Daniel da Costa Dantas ${ }^{2 *}$ (D) Ênio Farias de França e Silva², Mario Monteiro Rolim², \\ Manassés Mesquita da Silva², José Edson Florentino de Morais², Raquele Mendes Lira ${ }^{2}$
}

10.1590/0034-737X201966010005

\begin{abstract}
This study aimed to evaluate production components of sunflower (Helianthus annuus L.) plants irrigated with domestic wastewaters treated by different processes, with two irrigation depths. The experiment was carried out in Ibimirim, state of Pernambuco, Brazil, using a randomized block design in a $4 \times 2$ factorial arrangement, with four replications. The treatments consisted of four irrigation water types (domestic wastewater treated by UASB reactor - $\mathrm{DW}_{1}$; domestic wastewater treated by digestion decanter and anaerobic filtration - $\mathrm{DW}_{2}$; domestic wastewater treated by anaerobic filtration - $\mathrm{DW}_{3}$; and public water - $\mathrm{PW}_{4}$ ) and two irrigation depths (equal to the crop evapotranspiration - $\mathrm{ID}_{1}$; and $20 \%$ higher than the crop evapotranspiration - $\mathrm{ID}_{2}$ ). The production components—plant fresh and dry weights, 1000-achene weight, capitulum internal diameter, achene yield, oil content, and oil yield - were evaluated at the end of the crop cycle. The irrigation with treated domestic wastewater improved all variables analyzed when compared to the drinking water, especially when using $\mathrm{DW}_{2}$ and $\mathrm{DW}_{3}$ with $\mathrm{ID}_{1}$.
\end{abstract}

Keywords: water reuse; household effluents; sewage treatment; Helianthus annuиs L.

\section{RESUMO}

\section{Componentes de produção do girassol irrigado com esgotos domésticos tratados e água de abastecimento em região semiárida}

Objetivou-se avaliar os componentes de produção do girassol (Helianthus annuus L.) irrigado com esgotos domésticos tratados por diferentes processos e duas lâminas de irrigação. O experimento foi realizado em Ibimirim-PE, Brasil. Utilizou-se o delineamento em blocos ao acaso, em esquema fatorial 4 × 2, com quatro repetições. Os tratamentos consistiram da utilização de dois fatores: tipos de águas de irrigação $\left(\mathrm{ED}_{1}\right.$ - esgoto tratado por reator UASB, $\mathrm{ED}_{2}$ - esgoto tratado por decanto digestor e filtragem anaeróbia, $\mathrm{ED}_{3}$ - esgoto tratado por filtragem anaeróbia e $\mathrm{AB}_{4}$ - água de abastecimento) e lâminas de irrigação $\left(L_{1}\right.$ - igual à evapotranspiração da cultura e $L_{2}-20 \%$ superior à evapotranspiração da cultura). Ao final do ciclo da cultura, mensurou-se as variáveis relacionadas à produção: biomassa fresca e seca por planta, massa de mil aquênios, diâmetro interno do capítulo, produtividade de aquênios, teor e produtividade de óleo. Verificou-se que a irrigação com esgotos domésticos tratados proporcionou aumentos em todas as variáveis analisadas em relação à água de abastecimento, principalmente quando se fez uso das águas $\mathrm{ED}_{2} \mathrm{e} \mathrm{ED}_{3}$ com a lâmina $\mathrm{L}_{1}$.

Palavras-chave: reúso de água; efluentes domésticos; tratamentos de esgoto; Helianthus annuus L.

\footnotetext{
Subjected on March $09^{\text {th }}, 2018$ and accepted on January $19^{\text {th }}, 2019$

${ }^{1}$ This work is part of the first author's doctoral thesis.

2Universidade Federal Rural de Pernambuco, Departamento de Engenharia Agrícola, Recife, Pernambuco, Brazil. d1cdantas@hotmail.com; enio.fsilva@ufrpe.br; mario.monteiro@ufrpe.br; manasses.mesquita@ufrpe.br; joseedson50@hotmail.com; raquelelira@gmail.com

*Corresponding author: d1cdantas@hotmail.com
}

Rev. Ceres, Viçosa, v. 66, n.1, p. 034-040, jan/fev, 2019 


\section{INTRODUCTION}

Water scarcity and quality have become a worldwide concern. The increase in the world population requires to increase food production, which generates greater water demand for agricultural activities (Savvas et al., 2007; Cunha et al., 2011; Nikolaou et al., 2017).

Large volumes of domestic wastewater (DW) are released into the environment without adequate treatment causing damage to ecosystems (Bezerra \& Fideles Filho, 2009). In Brazil, more than $90 \%$ of the domestic wastewater and approximately $70 \%$ of industrial effluents are released directly into water bodies without any treatment (Brasil, 2015).

Water reuse is not a new concept, but the increasing demand for water has turn planned water reuse into an important issue. Treated wastewater is important for the sustainable management of water resources for agriculture; it increases the water volume available and contribute to plant nutrition (Cunha et al., 2011; Santos Júnior et al., 2015).

The use of domestic wastewater in agriculture reduces pollution of water courses, saves good quality water, and lowers mineral fertilization costs (Deon et al., 2010; Barbosa et al., 2017; Gonçalves et al., 2017).

DW should be treated to the secondary level for agricultural production purposes to reduce organic matter content and maintain essential nutrients to crops (Silva et al., 2012). Anaerobic processes are widely used because they are efficient, fast, and low-cost methods (Singh \& Prerna, 2009). Several types of anaerobic reactors can be used for wastewater treatment, such as the upflow anaerobic sludge blanket (UASB), digestion decanters, anaerobic filters, and combined processes.

Evaluations of the performance of crops irrigated with treated domestic wastewater have been carried out in Brazil (Nobre et al., 2010; Freitas et al., 2012; Orrico Junior et al., 2013; Bezerra et al., 2014; Santos Junior et al., 2011; Santos Junior et al., 2015; Barbosa et al., 2017; Gonçalves et al., 2017), with most of them finding improvements when comparing to irrigations with public water. In this context, the objective of this work was to evaluate production components of sunflower (Helianthus annus L.) plants grown in the Semiarid region of Brazil, irrigated with domestic wastewater treated by different processes, with two irrigation depths.

\section{MATERIALAND METHODS}

The experiment was carried out in Ibimirim, state of Pernambuco, Brazil, at the Pilot Unit of Water Reuse in Agriculture ( $8^{\circ} 32^{\prime} 05^{\prime \prime} \mathrm{S}, 37^{\circ} 41^{\prime} 58^{\prime \prime} \mathrm{W}$, and altitude of $408 \mathrm{~m}$ ).
The region has a BSw'h', very hot and dry climate, with a rainy season in the summer that can last until early fall, according to the Köppen classification, with average annual rainfall of $454 \mathrm{~mm}$ and average annual air temperature of $24.7{ }^{\circ} \mathrm{C}$ (Alvares et al. 2014; Instituto Nacional de Meteorologia - INMET, 2018). During the experiment, the average air temperature was $26.9^{\circ} \mathrm{C}$ and the accumulated rainfall depth was $175.2 \mathrm{~mm}$ (Figure 1).

The soil of the experimental area was classified as Entisol, with a moderate A horizon, and flat relief (Empresa Brasileira de Pesquisa Agropecuária - Embrapa, 2013). A chemical analysis of the $0-0.40 \mathrm{~m}$ soil layer was performed according to the methodology of Embrapa (2011) before the application of the DW. The soil presented $\mathrm{pH}\left(\mathrm{H}_{2} \mathrm{O}\right)$ of $7.0 ; 2.2 \mathrm{~g} \mathrm{~kg}^{-1}$ of total organic carbon, $56.85 \mathrm{mg} \mathrm{kg}^{-1}$ of $\mathrm{P}$ (Mehlich 1), $0.25 \mathrm{cmol}_{\mathrm{c}} \mathrm{dm}^{-3}$ of K, $2.15 \mathrm{cmol}_{\mathrm{c}} \mathrm{dm}^{-3}$ of $\mathrm{Ca}, 2.2$ cmol $\mathrm{dm}^{-3}$ of Mg, $3.1 \mathrm{cmol}_{\mathrm{c}} \mathrm{dm}^{-3}$ of $\mathrm{H}+\mathrm{Al}$, sum of bases of $5 \mathrm{cmol}_{\mathrm{c}} \mathrm{dm}^{-3}$, cation exchange capacity of $8.05 \mathrm{cmol}_{\mathrm{c}} \mathrm{dm}^{-3}$, and base saturation of $63.1 \%$. Therefore, the soil had good fertility, intermediate cation exchange capacity at pH 7.0, intermediate potential acidity, and good organic carbon content (Alvarez et al., 1999).

The experiment was conducted using a randomized block experimental design in a $4 \times 2$ factorial arrangement, with four replications. The treatments consisted of four irrigation water types (domestic wastewater treated by UASB reactor - $\mathrm{DW}_{1}$; domestic wastewater treated by digestion decanter and anaerobic filtration - $\mathrm{DW}_{2}$; domestic wastewater treated by anaerobic filtration - $\mathrm{DW}_{3}$; and public water - $\mathrm{PW}_{4}$ ) and two irrigation depths (equal to the crop evapotranspiration - $\mathrm{ID}_{1}$; and $20 \%$ higher than crop evapotranspiration - $\mathrm{ID}_{2}$ ).

The experimental unit consisted of three 6-meter planting rows. The sunflower seeds were sown with spacing of $0.25 \mathrm{~m}$ between plants and $1.0 \mathrm{~m}$ between rows, using the Helio-250 cultivar. A drip irrigation system was used, consisted of a polyethylene tube of $16 \mathrm{~mm}$ diameter with emitters spaced $0.33 \mathrm{~m}$ apart, flow rate of $4.0 \mathrm{~L} \mathrm{~h}^{-1}$, and average operating pressure of $103 \mathrm{kPa}$. The mean coefficient of distribution uniformity of the system was $89 \%$.

The irrigation depths were defined according to the crop evapotranspiration (ETc), using the crop coefficient (Kc) and reference evapotranspiration (ETo), through the Penman-Monteith method, standardized by the United Nations for Food and Agriculture - FAO (Allen et al., 1998). The mean Kc found were 0.35 for the crop initial stages of germination, emergence, and establishment (20 to 25 days), 0.75 for the vegetative stage (35 to 40 days), 1.15 for the flowering stage (40 to 50 days), 0.75 for the grain filling stage (25 to 30 days), and 0.4 for the physiological maturation stage (Doorenbos \& Kassam, 1979). The mean location coefficient was determined according to the methodology of Albuquerque et al. (2011). 
Irrigation depths were altered according to the treatments at 27 day after sowing (DAS), with plants in $\mathrm{ID}_{2}$ receiving $20 \%$ more water than those in $\mathrm{ID}_{1}$, totaling $315.5 \mathrm{~mm}\left(\mathrm{ID}_{1}\right)$ and $370.2 \mathrm{~mm}\left(\mathrm{ID}_{2}\right)$ at the end of the cycle (Figure 1).

The physical-chemical ( $\mathrm{pH}$, electrical conductivity, chemical oxygen demand, and biochemical oxygen demand), chemical ( $\mathrm{N}, \mathrm{P}, \mathrm{K}, \mathrm{Ca}, \mathrm{Mg}, \mathrm{Na}, \mathrm{Cl}$, sodium adsorption ratio (SAR), $\mathrm{SO}_{4}^{-2}, \mathrm{CaCO}_{3}$ ), and physical (total suspended solids) parameters of the irrigation waters used were analyzed according to the Standard Methods for the Examination of Wastewater (APHA, 2012).

The plant fresh weight (PFW), plant dry weight (PDW), capitulum internal diameter (CID), 1000-achene weight (1000AW), achene production per plant (APP), achene yield (AY), oil content (AOC), and oil yield (AOY) were evaluated at 96 DAS. A grain moisture content of $11 \%$ was used to calculate 1000AW, APP, AY, AOC, and AOY. The Soxhlet extraction method was used to determine AOC (Bezerra Neto \& Barreto, 2011).

The data were subjected to analysis of variance by the $\mathrm{F}$ test $(p<0.05)$. The orthogonal contrasts $1-\mathrm{DW}_{1} \times \mathrm{DW}_{2}$, $2-\mathrm{DW}_{1} \times \mathrm{DW}_{3}, 3-\mathrm{DW}_{1} \times \mathrm{PW}_{4}, 4-\mathrm{DW}_{2} \times \mathrm{DW}_{3}, 5-\mathrm{DW}_{2}$ $\times\left(\mathrm{DW}_{1}+\mathrm{DW}_{3}\right), 6-\mathrm{PW}_{4} \times\left(\mathrm{DW}_{1}+\mathrm{DW}_{2}+\mathrm{DW}_{3}\right)$, and $7-\mathrm{ID}_{1}$ $\times \mathrm{ID}_{2}$ - were tested when the interaction between the factors was significant, using the SISVAR program (Ferreira, 2011).

\section{RESULTS AND DISCUSSION}

The average $\mathrm{N}, \mathrm{P}, \mathrm{K}$, and $\mathrm{Ca}$ contents in the domestic wastewater used in the experiment were 88.5, 9.4, 46.5, and $136.6 \mathrm{mg} \mathrm{L}^{-1}$ respectively (Table 1). Considering the applied irrigation depth in ID of $315.5 \mathrm{~mm}$, the domestic wastewater contributed with 279.2, 29.8, 146.8, and 437.3 $\mathrm{kg} \mathrm{ha}^{-1}$ of $\mathrm{N}, \mathrm{P}, \mathrm{K}$, and Ca respectively, improving soil fertility, and discarding the need for commercial fertilizer applications. However, the domestic wastewater presented electrical conductivity of $2.0 \mathrm{dS} \mathrm{m}^{-1}$ and SAR of 1.82. According to Richards (1954), this type of water is classified as $\mathrm{C} 3 \mathrm{~S} 1$, present high risk of salinization, and can be used in soils with good drainage and with crops that present moderate tolerance to salinity. This denotes the need for studies of specific managements, such as the use of leaching fraction.

The use of domestic wastewater had significant effect on all variables evaluated, when compared to the public water $\left(\mathrm{PW}_{4}\right)$ (Table 2 - Contrast 6$)$. Average increases of $333.6 \mathrm{~g}$ in PFW, $53.7 \mathrm{~g}$ in PDW, $3.23 \mathrm{~cm}$ in CID, and $18.1 \mathrm{~g}$ in $1000 \mathrm{AW}$ were found, which increased AY to $1,614.4 \mathrm{~kg}$ ha${ }^{1}$ and AOY to $703 \mathrm{~kg} \mathrm{ha}^{-1}$.

The average PDW of plants irrigated with domestic wastewater $\left(\mathrm{DW}_{1}, \mathrm{DW}_{2}\right.$, and $\left.\mathrm{DW}_{3}\right)$ was $85.6 \mathrm{~g}$, and $32 \mathrm{~g}$ with $\mathrm{PW}_{4}$, denoting an average increment of $167 \%$ due to the use of wastewater. These results were higher than those found by Nobre et al. (2010) who found PDW of 10.9 to $41.5 \mathrm{~g}$ with increasing irrigation depths with domestic effluent, and organic fertilization, in a protected environment. An expressive increase in PDW of sunflower, which can be incorporated into the soil, or used for animal feed, can be obtained with the use of treated domestic wastewater in the irrigation water. According to Garcez et al. (2015), sunflower crop residues presents good degradability and can be included in diets of ruminants.

Plants irrigated with the domestic wastewater had higher $1000 \mathrm{AW}$, with no significant difference between them. The irrigation depths generated significant differences only when using $\mathrm{DW}_{1}$, in which the use of $\mathrm{ID}_{1}$ resulted in an $1000 \mathrm{AW}$ of $27.7 \mathrm{~g}(46.2 \%)$ higher than $\mathrm{ID}_{2}$ (Table 3 ). This effect was probably because of the precipitation of part of the calcium and phosphorus as calcium phosphate in the $\mathrm{DW}_{1}$, which was higher when using the $\mathrm{ID}_{2}$; whereas plants in $\mathrm{PW}_{4}$ had lower $1000 \mathrm{AW}$ due to nutrient deficit. The use of $\mathrm{ID}_{2}$ increased the 1000 AW of plants treated with $\mathrm{DW}_{2}(84.8 \mathrm{~g})$ and $\mathrm{DW}_{3}(75.3 \mathrm{~g})$ in $35.02 \%$, on average, when compared to those of plants treated with $\mathrm{DW}_{1}$ and $\mathrm{PW}_{4}$.

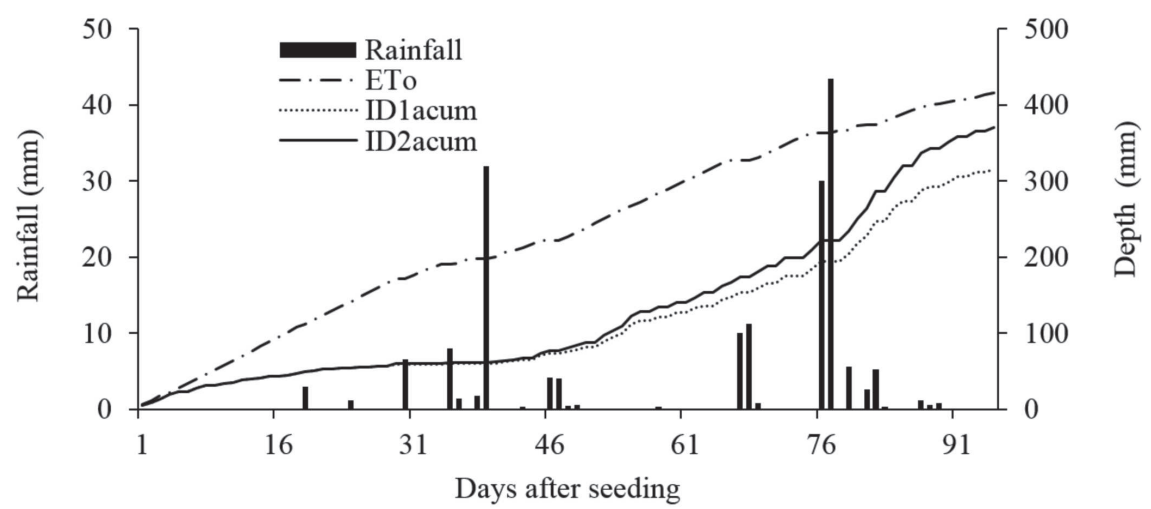

Figure 1: Rainfall depths, reference evapotranspiration, and accumulated irrigation depths during the experiment. 
The 1000AW found were similar to those found by Aquino et al. (2013), who evaluated the same sunflower cultivar and found 1000AW of $86 \mathrm{~g}$. In addition, Capone et al. (2011) and Pivetta et al. (2012) found 1000AW of 29.25 to $46.86 \mathrm{~g}$ in non-irrigated crops.

Plants irrigated with $\mathrm{PW}_{4}$ had mean achene yield (AY) of $1,677.5 \mathrm{~kg} \mathrm{ha}^{-1}$, and those irrigated with treated DW had mean AY of 3,291.9 $\mathrm{kg} \mathrm{ha}^{-1}$ (Table 2), representing an increase of $96.2 \%$. These AY were higher than the national average in the 2016/17 harvest $\left(1,419 \mathrm{~kg} \mathrm{ha}^{-1}\right)$ (Companhia Nacional de Abastecimento - Conab, 2017) and higher than that found by Bezerra et al. (2014) $\left(2,987.5 \mathrm{~kg} \mathrm{ha}^{-1}\right)$, who evaluated the effect of irrigation with treated wastewater and nitrogen rates in sunflower crops in Aquiraz, CE, Brazil. However, the AY were lower than those found by Aquino et al. (2013) $\left(3,950 \mathrm{~kg} \mathrm{ha}^{-1}\right)$, who evaluated sunflower cultivars with mineral fertilization applied at planting (250 $\mathrm{kg} \mathrm{ha}^{-1}$ of 8-28-16 N-P-K) and as top-dressing (80-0-60 kg ha-1 of N-P-K).

The higher AY of plants with the use of $\mathrm{PW}_{4}$ when compared to the national yield can be due to the benefits of irrigation, through the maintenance of soil moisture and soil nutrient availability. The Helio-250 cultivar was evaluated in different sites in the Northeast region of Brazil, showing AY of 1,052 to 3,425 $\mathrm{kg} \mathrm{ha}^{-1}$ (Empresa Brasileira de Pesquisa Agropecuária - Embrapa, 2010).

Increases in $\mathrm{AY}$ due to irrigation with domestic wastewater were found by Lobo \& Grassi Filho (2007) and Nobre et al. (2010), who evaluated the efficiency of sewage sludge in supplying nitrogen, and water for sunflower crops.

$\mathrm{DW}_{2}$, and $\mathrm{DW}_{3}$ presented no significant differences $(p \geq 0.05)$ in any variable analyzed (Table 2 - Contrast 4$)$, denoting similarity between them. However, a significant effect $(p<0.05)$ in AY was found between Contrasts 1 $\left(\mathrm{DW}_{1} \times \mathrm{DW}_{2}\right)$ and $2\left(\mathrm{DW}_{1} \times \mathrm{DW}_{3}\right)$ (Table 2$)$, denoting higher AY with the use of $\mathrm{DW}_{2}\left(3,644.4 \mathrm{~kg} \mathrm{ha}^{-1}\right)$, and $\mathrm{DW}_{3}(3,462.2$ $\mathrm{kg} \mathrm{ha}^{-1}$ ) (Table 2). The use of DW, resulted in a lower AY than the use of $\mathrm{DW}_{2}$, or $\mathrm{DW}_{3}$ due to its lower sulfate concentration $\left(\mathrm{SO}_{4}^{-2}\right)$ (Table 1), making sulfur a limiting nutrient to the development of the crop, since this element is important to the synthesis of amino acids (Taiz et al., 2017). Tiecher et al. (2012) found significant linear effect for the response of sunflower crops to sulfate fertilization, with increases in seed sulfur contents with increasing sulfate rates.

Achene oil content (AOC) had an average variation of $33 \%$ to $38.9 \%$ according to the irrigation water type. The analysis of the irrigation water types within each irrigation depth showed better results for the plots irrigated with domestic wastewater with $\mathrm{ID}_{1}$ when compared to $\mathrm{PW}_{4}$; and no significant difference $(p \geq 0.05)$ was found for $\mathrm{ID}_{2}$. The effect of the different irrigation 
depths in each type of water was significant only for $\mathrm{PW}_{4}$, with a $25.2 \%$ increase in AOC when using $\mathrm{ID}_{2}$ (Table 3). Thomaz et al. (2012) evaluated the effect of different sowing times on achenes production and oil content and found AOC ranging from 37 to $52 \%$.

The achene oil yield (AOY) of the treatments $\mathrm{DW}_{2}$ $\left(1,415.5 \mathrm{~kg} \mathrm{ha}^{-1}\right)$ and $\mathrm{DW}_{3}\left(1,319.3 \mathrm{~kg} \mathrm{ha}^{-1}\right)$ were significantly higher than those of the other treatments $(p<0.05)$. The irrigation depths were also significant for AOY (Table 2); ID resulted in an AOY of $16.53 \%$. Gomes et al. (2012) found different results (linear effect), with increases in AOY of sunflower (Aragua 4 cultivar) with increasing irrigation depths.

The use of treated domestic wastewater significantly improved production variables in the region evaluated, where most plantations are carried out in rainfed systems, with no guarantee of harvest. Therefore, the use of treated domestic wastewater for irrigation is an alternative for this crop in regions with water scarcity.
Despite the benefits of using treated domestic wastewater, this technology requires adequate practices for treatment and disposal in the environment, since treated domestic wastewaters have considerable concentrations of dissolved ions such as sodium, boron, and chlorides, and contain diverse pathogenic organisms such as bacteria, viruses, protozoa, and helminths (Sousa et al., 2003; Hespanhol, 2009). Therefore, an inadequate management of these wastewaters can harm the environment, human health, soil, aquifers, and irrigated crops (Duarte et al., 2008). Moreover, this can cause soil salinization and sodification, excess nitrate in the soil solution, and contamination of the water table (World Health Organization - WHO, 2006; Dantas et al., 2018).

Therefore, the maintenance of the sustainability of crops requires the monitoring of soil chemical, physical, and microbiological properties and the products originating from these areas, and the use of rotational strategies to avoid harmful levels of contamination.

Table 2: Contrast test for plant fresh weight (PFW), plant dry weight (PDW), 1000 achene weight (1000AW), capitulum internal diameter (CID), achene yield (AY), oil content (AOC), and oil yield (AOY) of sunflower plants of the Helio-250 cultivar irrigated with different depths $\left(\mathrm{ID}_{1}\right.$ and $\left.\mathrm{ID}_{2}\right)$ of treated domestic wastewaters $\left(\mathrm{DW}_{1}, \mathrm{DW}_{2}\right.$, and $\left.\mathrm{DW}_{3}\right)$, and public water $\left(\mathrm{PW}_{4}\right)$.

\begin{tabular}{|c|c|c|c|c|c|c|c|}
\hline \multirow{2}{*}{ Contrasts } & PFW & PDW & CID & 1000AW & $\mathbf{A Y}$ & AOC & AOY \\
\hline & \multicolumn{7}{|c|}{$\mathbf{F}$} \\
\hline $1-\mathrm{DW}_{1} \times \mathrm{DW}_{2}$ & $1.49^{\text {n.s. }}$ & $2.74^{\text {n.s. }}$ & $2.69^{\text {n.s. }}$ & $3.11^{\text {n.s. }}$ & $9.67 * *$ & $3.39^{\text {n.s. }}$ & $13.71 * *$ \\
\hline $2-\mathrm{DW}_{1} \times \mathrm{DW}_{3}$ & $0.27^{\text {n.s. }}$ & $0.19^{\text {n.s. }}$ & $2.21^{\text {n.s. }}$ & $1.70^{\text {n.s. }}$ & $6.06^{*}$ & $3.39^{\text {n.s. }}$ & $7.89 *$ \\
\hline $3-\mathrm{DW}_{1} \times \mathrm{PW}_{4}$ & $73.69 * *$ & $64.97 * *$ & $8.67 * *$ & $5.93^{*}$ & $15.04 * *$ & $4.11^{\text {n.s. }}$ & $18.92 * *$ \\
\hline $4-\mathrm{DW}_{2} \times \mathrm{DW}_{3}$ & $0.49^{\text {n.s. }}$ & $1.48^{\text {n.s. }}$ & $0.23^{\text {n.s. }}$ & $0.21^{\text {n.s. }}$ & $0.42^{\text {n.s. }}$ & $0.26^{\text {n.s. }}$ & $0.79^{\text {n.s. }}$ \\
\hline $5-\mathrm{DW}_{2} \times\left(\mathrm{DW}_{1}+\mathrm{DW}_{3}\right)$ & $1.23^{\text {n.s. }}$ & $2.75^{\text {n.s. }}$ & $1.07^{\text {n.s. }}$ & $1.65^{\text {n.s. }}$ & $4.70 *$ & $1.84^{\text {n.s. }}$ & $7.03 *$ \\
\hline $6-\mathrm{PW}_{4} \times\left(\mathrm{DW}_{1}+\mathrm{DW}_{2}+\mathrm{DW}_{3}\right)$ & $126.02 * *$ & $115.07 * *$ & $23.86 * *$ & $17.94 * *$ & $49.34 * *$ & $14.28 * *$ & $63.79 * *$ \\
\hline $7-\mathrm{ID}_{1} \times \mathrm{ID}_{2}$ & $2.46^{\text {n.s. }}$ & $2.16^{\text {n.s. }}$ & $0.65^{\text {n.s. }}$ & $7.36^{*}$ & $4.35 *$ & $0.08^{\text {n.s. }}$ & $4.63 *$ \\
\hline \multirow{2}{*}{ Treatments } & \multicolumn{7}{|c|}{ Means } \\
\hline & (g) & (g) & $(\mathbf{c m})$ & (g) & $\left(\mathrm{Kg} \mathrm{ha}^{-1}\right)$ & $(\%)$ & $\left(\mathrm{Kg} \mathrm{ha}^{-1}\right)$ \\
\hline$\overline{\mathrm{DW}_{1}}$ & 472 & 81.4 & 13.7 & 73.8 & 2769.2 & 36.1 & 1016.4 \\
\hline $\mathrm{DW}_{2}$ & 516.5 & 91.5 & 15.0 & 83.1 & 3644.4 & 38.9 & 1415.5 \\
\hline $\mathrm{DW}_{3}$ & 491 & 84.1 & 14.9 & 80.7 & 3462.2 & 38.2 & 1319.3 \\
\hline $\mathrm{PW}_{4}$ & 159.6 & 32 & 11.3 & 61.1 & 1677.5 & 33 & 547.4 \\
\hline $\mathrm{ID}_{1}$ & 389.6 & 69.1 & 13.5 & 79.7 & 3095.9 & 36.4 & 1156.7 \\
\hline $\mathrm{ID}_{2}$ & 430 & 75.4 & 13.9 & 69.7 & 2680.7 & 36.7 & 992.64 \\
\hline
\end{tabular}

* significant at 0.05 probability level; ** significant at 0.05 probability level; ${ }^{\text {n.s. }}$ not significant at 0.05 probability level by the $\mathrm{F}$ test.

Table 3: Achene oil content (AOC) and 1000 achene weight (1000AW) of sunflower plants of the Helio-250 cultivar irrigated with different depths $\left(\mathrm{ID}_{1}\right.$, and $\left.\mathrm{ID}_{2}\right)$ of treated domestic wastewaters $\left(\mathrm{DW}_{1}, \mathrm{DW}_{2}\right.$, and $\left.\mathrm{DW}_{3}\right)$, and public water $\left(\mathrm{PW}_{4}\right)$.

\begin{tabular}{|c|c|c|c|c|c|}
\hline \multirow{2}{*}{ Treatments } & \multicolumn{2}{|c|}{ 1000AW } & \multicolumn{3}{|c|}{$\operatorname{AOC}(\%)$} \\
\hline & ID $_{1}$ & $\mathrm{ID}_{2}$ & $\mathrm{ID}_{1}$ & $\mathrm{ID}_{2}$ & \\
\hline$\overline{\mathrm{DW}_{1}}$ & $87.7 \mathrm{aA}$ & $59.9 \mathrm{bB}$ & 38.1 & aA 34.2 & $\mathrm{aA}$ \\
\hline $\mathrm{DW}_{2}$ & $81.3 \mathrm{aA}$ & $84.8 \mathrm{aA}$ & 39.9 & aA 38.0 & $\mathrm{aA}$ \\
\hline $\mathrm{DW}_{3}$ & $86.1 \mathrm{aA}$ & $75.3 \mathrm{aA}$ & 38.4 & aA 38.0 & $\mathrm{aA}$ \\
\hline $\mathrm{PW}_{4}$ & $63.6 \mathrm{bA}$ & $58.6 \mathrm{bA}$ & 29.3 & bB 36.7 & $\mathrm{aA}$ \\
\hline
\end{tabular}

Means followed by different uppercase letters in the columns, or different lowercase letters in the rows do not differ by the Skott-Knott test at 0.05 probability level.

Rev. Ceres, Viçosa, v. 66, n.1, p. 034-040, jan/fev, 2019 


\section{CONCLUSIONS}

The use of treated domestic wastewater for irrigation of sunflower plants increased achene yield and oil content; thus, it is an alternative to improve the crop production in regions with water scarcity;

The use of treated domestic wastewater provided significant gains in all variables evaluated when compared to the irrigation with public water;

The wastewaters treated by digestion decanter and anaerobic filtration $\left(\mathrm{DW}_{2}\right)$, and by anaerobic filtration $\left(\mathrm{DW}_{3}\right)$ provided higher achene and oil yields.

\section{ACKNOWLEDGMENTS}

The authors thank the National Council of Scientific and Technological Development CNPq for the financial support for this research.

\section{REFERENCES}

Albuquerque FS, Silva EFF, Albuquerque Filho JAC \& Nunes MFFN (2011) Crescimento e rendimento de pimentão fertigado sob diferentes lâminas de irrigação e doses de potássio. Revista Brasileira Engenharia Agrícola Ambiental, 15:686-694.

Allen RG, Pereira LS, Raes D \& Smith M (1998) Crop evapotranspiration-guidelines for computing crop water requirements. Rome, FAO Irrigation and Drainage. 56p.

Alvares CA, Stape JL, Sentelhas PC, Gonçalves JLM \& Sparovek G (2014) Köppen'sclimate classification map for Brazil. Meteorologische Zeitschrift, 22:711-728.

Alvarez VVH, Novais RF, Barros NF, Cantarutti RB \& Lopes AS (1999) Interpretação dos resultados das análises de solos. In: Ribeiro AC, Guimarães PTG \& Alvarez VVH, (Eds.) Recomendação para o uso de corretivos e fertilizantes em Minas Gerais. Viçosa, CFSEMG. 359p.

APHA, AWWA, WEF (2012) Standard methods for examination of water and wastewater. $22^{a}$ ed. Washington, American Public Health Association. 1360p.

Aquino LA, Silva FDB \& Berger PG (2013) Características agronômicas e o estado nutricional de cultivares de girassol irrigado. Revista Brasileira de Engenharia Agrícola e Ambiental, 17:551-557.

Barbosa EAA, Matsura EE, Santos LNS, Gonçalves IZ, Nazario AA \& Feitosa DRC (2017) Water footprint of sugarcane irrigated with treated sewage and freshwater under subsurface drip irrigation, in Southeast Brazil. Journal of Cleaner Production, 153:448-456.

Bezerra BG \& Fideles Filho J (2009) Análise de crescimento da cultura do algodoeiro irrigada com águas residuárias. Revista Ciência Agronômica, 40:339-345.

Bezerra FML, Freitas CAS, Silva ARA, Mota SB \& Aquino BF (2014) Irrigation with domestic treated sewage and nitrogen fertilizing in sunflower cultivation. Engenharia Agrícola, 34:1186-1200.

Bezerra Neto E \& Barreto LP (2011) Análises químicas e bioquímicas em plantas. Recife, Universidade Federal Rural de Pernambuco. 267p.

Brasil (2015) Água: Manual de Uso. Brasília, Secretaria de Recursos Hídricos/Ministério do Meio Ambiente. 135p.
Capone A, Barros HB, Santos ER, Santos AF, Ferraz EC \& Fidelis RR (2011) Épocas de semeadura de girassol safrinha após milho, em plantio direto no cerrado tocantinense. Revista Brasileira de Ciências Agrárias, 06:460-466.

Conab - Companhia Nacional de Abastecimento (2017) Girassol Conjuntura Mensal - Março de 2017. Disponível em: http:// www.conab.gov.br/OlalaCMS/uploads/arquivos/ 17_04_10_10_06_42_girassol_-_conjuntura_mensal__marco_de_2017.pdf. Acessado em: 02 de Abril de 2018.

Cunha AHN, Oliveira THO, Ferreira RB, Milhardes ALM \& Silva SMC (2011) O reúso de água no Brasil: a importância da reutilização de água no país. Centro Científico Conhecer, 07:1225-1248.

Dantas DC, Silva EFF, Dantas MSM, Silva GF, Santos NA \& Rolim MM (2018) Cultivation of sunflower irrigated with domestic sewage treated in Quartzarenic Neosol. Revista Brasileira de Ciencias Agrarias, 13:01-06.

Deon MD, Gomes TM, Melf AJ, Montes CR \& Silva E (2010) Produtividade e qualidade da cana-de-açúcar irrigada com efluente de estação de tratamento de esgoto. Pesquisa Agropecuária Brasileira, 45:1149-1156

Doorenbos J \& Kassam AH (1979) Yield response to water. Rome: FAO. 193p. (Irrigation and drainage paper, 33).

Duarte AS, Airoldi RPS, Folegatti MV, Botrel TA \& Soares TM (2008) Efeitos da aplicação de efluente tratado no solo: pH, matéria orgânica, fósforo e potássio. Revista Brasileira de Engenharia Agrícola e Ambiental, 12:302-310.

Embrapa - Empresa Brasiileira de Pesquisa Agropecuária (2010) Avaliação de cultivares de girassol em municípios dos Estados da Bahia, Alagoas, Sergipe e Rio Grande do Norte: ensaios realizados no ano agrícola de 2008. Disponível em: http:// www.cpatc.embrapa.br/publicacoes_2010/cot_105.pdf. Acessado em: 28 de março de 2018.

Embrapa - Empresa Brasiileira de Pesquisa Agropecuária (2013) Sistema brasileiro de classificação de solos. $3^{\text {a }}$ ed. Brasília, Embrapa. 353p.

Embrapa - Empresa Brasileira de Pesquisa Agropecuária (2011) Manual de métodos de análise de solo. $2^{\text {a }}$ ed. Rio de Janeiro, Embrapa. 212p.

Ferreira DF (2011) Sisvar: a computer statistical analysis system. Ciência e Agrotecnologia, 35:1039-1042

Freitas CAS, Silva ARA, Bezerra FML, Andrade RR, Mota FSB \& Aquino BF (2012) Crescimento da cultura do girassol irrigado com diferentes tipos de água e adubação nitrogenada. Revista Brasileira de Engenharia Agrícola e Ambiental, 16:1031-1039.

Garcez BS, Alves AA, Oliveira DS, Santana YAG, Moreira Filho MA \& Reis JAM (2015) Degradabilidade ruminal do feno do restolho da cultura do girassol em dois tamanhos de partículas. Acta Veterinaria Brasilica, 09:148-152.

Gomes EP, Fedri G, Ávila MR, Biscaro GA, Rezende RKS \& Jordan RA (2012) Produtividade de grãos, óleo e massa seca de girassol sob diferentes lâminas de irrigação suplementar. Revista Brasileira de Engenharia Agrícola e Ambiental, 16:237-246.

Gonçalves IZ, Barbosa EAA, Santos LNS, Nazário AA, Feitosa DRC, Tuta NF \& Matsura EE (2017) Water relations and productivity of sugarcane irrigated with domestic wastewater by subsurface drip. Agricultural Water Management, 185:105115 .

Hespanhol I (2009) Viabilidade de um $\operatorname{AVAD}(*)$ não superior a 104 por pessoa por ano, para reuso agrícola de água, em países em desenvolvimento. Ambi-Água, 04:124-134. 
INMET - Instituto Nacional de Meteorologia (2018) Normal Climatológica do Brasil 1981-2010. Disponível em: http:// ww w. in met.gov.br/portal/index.ph p ? r = cli ma/ normaisclimatologicas. Acessado em: 01 de Abril de 2018.

Lobo TF \& Grassi Filho H (2007) Níveis de lodo de esgoto na produtividade do girassol. Revista de la Ciência del Suelo y Nutrición Vegetal, 07:16-25.

Nikolaou G, Neocleous D, Katsoulas N \& Kittas C (2017) Effect of irrigation frequency on growth and production of a cucumber crop under soilless culture. Emirates Journal of Food and Agriculture, 29:863-871.

Nobre RG, Gheyi HR, Soares FAL, Andrade LO \& Nascimento ECS (2010) Produção do girassol sob diferentes lâminas com efluentes domésticos e adubação orgânica. Revista Brasileira Engenharia Agrícola Ambiental, 14:747-754.

Orrico Junior MAP, Orrico ACA, Centurion SR, Sunada NS \& Vargas Junior FM (2013) Características morfogênicas do capim-piatã submetido à adubação com efluentes de abatedouro avícola. Ciência Rural, 43:158-163.

Pivetta LG, Guimarães VF, Fioreze SL, Pivetta LA \& Gustavo Castoldi G (2012) Avaliação de híbridos de girassol e relação entre parâmetros produtivos e qualitativos. Revista Ciência Agronômica, 43:561-568.

Richards LA (1954) Diagnosis and improvement of saline and alkali soils Washington: U.S. Department of Agriculture, Handbook 60. 160p.

Santos Júnior JA, Gheyi HR, Guedes Filho DH, Dias NS \& Soares FAL (2011) Cultivo de girassol em sistema hidropônico sob diferentes níveis de salinidade. Revista Ciência Agronômica, 42:842-849.

Santos Júnior JA, Souza CF, Pérez-Marin AM, Cavalcante AR \& Medeiros SS (2015) Interação urina e eûuente doméstico na produção do milheto cultivado em solos do semiárido paraibano. Revista Brasileira de Engenharia Agrícola e Ambiental, 19:456463 .
Savvas D, Stamati E, Tsirogiannis IL, Mantzos N, Barouchas PE, Katsoulas N \& Kittas C (2007) Interactions between salinity and irrigation frequency in greenhouse pepper grown in closedcycle hydroponic systems. Agricultural Water Management, 91:102-111.

Silva MM, Medeiros PRF \& Silva EFF (2012) Reúso da água proveniente de esgoto doméstico tratado para a produção agrícola no semiárido pernambucano. In: Gheyi HR, Silva Paz VP, Medeiros SS \& Galvão CO (Eds.) Recursos hídricos em regiões semiáridas. Cruz das Almas, Instituto Nacional do Semiárido. p. 156-169.

Singh SP \& Prerna P (2009) Review of recent advances in anaerobic packed bed biogas reactors. Renewableand Sustainable Energy Reviews, 13:1569-1575.

Sousa JT \& Leite VD (2003) Tratamento e Utilização de Esgotos Domésticos na Agricultura. Campina Grande, Eduep. 135p.

Taiz L, Zeiger E, Møller IM, Murphy A (2017) Fisiologia e desenvolvimento vegetal. $6^{\mathrm{a}}$ ed. Porto Alegre, Artmed. 858p.

Thomaz GL, Zagonel J, Colasante LO \& Nogueira RR (2012) Produção do girassol e teor de óleo nas sementes em diferentes épocas de semeadura no Centro-Sul do Paraná. Ciência Rural, 42:203-208.

Tiecher T, Santos DR, Rasche JWA, Brunetto G, Mallmann FJK \& Piccin R (2012) Respostas de culturas e disponibilidade de enxofre em solos com diferentes teores de argila e matéria orgânica submetidos à adubação sulfatada. Bragantia, 71:518-527.

WHO - World Health Organization (2006) Guidelines for the safe use of wastewater, excreta and greywater. Volume 2: Wastewater use in Agriculture. Genebra, Suíça. 196p. 